\title{
Impact of humic acid as an organic additive on ruminal fermentation constituents, blood parameters and milk production in goats and their kids growth rate
}

\author{
H.M. El-Zaiat ${ }^{1,4}$, A.S. Morsy ${ }^{2}$, E.A. El-Wakeel ${ }^{3}$, M.M. Anwer ${ }^{3}$ and S.M. Sallam ${ }^{1}$ \\ ${ }^{1}$ Alexandria University, Faculty of Agriculture, Animal Production Department, P.O. Box 21545, Alexandria, Egypt \\ ${ }^{2}$ Arid Lands Cultivation Research Institute, Livestock Research Department, \\ City of Scientific Research and Technological Applications, New Borg El-Arab, P.O. Box 21934, Alexandria, Egypt \\ ${ }^{3}$ Agriculture Research Centre, Animal Production Research Institute, Sheep and Goats Research Department, \\ Dokki, P.O. Box 12618, Giza, Egypt
}

KEY WORDS: goats, digestibility, humic acid, milk production, ruminal fermentation

Received: 4 January 2018

Revised: 8 April 2018

Accepted: 14 June 2018
${ }^{4}$ Corresponding author:

e-mail: hani.elzaiat@alexu.edu.eg

\begin{abstract}
Impact of humic acid (HA) on ruminal fermentation characteristics, blood parameters and milk yield in goats and growth rate of their kids was determined. Twenty late pregnant Barki goats ( $45.4 \pm 1.5 \mathrm{~kg}$ body weight) were allocated into two treatments (10 goats per treatment), housed individually in closed pens (one goat per pen) and fed a total mixed ration (TMR) twice a day. The TMR was composed of $400 \mathrm{~g}$ roughage and $600 \mathrm{~g}$ concentrate mixture. Goats were fed either TMR without HA (control diet, CTL) or orally drenched with $\mathrm{HA}$ at a dose of $2 \mathrm{~g} \cdot \mathrm{d}^{-1}$ per goat (HA diet) for 14 days prepartum and 56 days postpartum. The results revealed that $\mathrm{HA}$ increased ruminal $\mathrm{pH}$, acetate and propionate proportions, while ammonia concentration and protozoa number were decreased. Administration of HA reduced daily dry matter intake and total faecal egg count. Animals treated with HA were characterised with increased blood total protein, globulin and glucose levels, while reduced blood urea nitrogen, cholesterol, non-esterified free fatty acids and $\beta$-hydroxybutyrate concentrations were stated. Milk, fat, lactose and protein yields increased, while milk urea nitrogen and somatic cell count decreased with HA treatment. Milk fat and protein contents were increased for goats treated with $\mathrm{HA}$. Kids reared by goats treated with $\mathrm{HA}$ had increased body weight and $31 \%$ greater daily weight gain than CTL ones. So, HA could be efficiently used as a promising organic additive to modulate ruminal fermentation pattern. Administration of HA improved milk yield and its quality in goats, and also growth rate of their kids with no adverse effects on animal health.
\end{abstract}

\section{Introduction}

In Mediterranean region small ruminants are constrained by malnutrition and seasonal fluctuation of feed supply. A strategy to improve animal productivity in countries with insufficient feed re- sources is an important target for ruminant nutritionists. Based on the growing concerns about the use of antibiotics in animal feeds, identifying organic alternatives as feed additives to modulate the rumen fermentation pattern and increase the efficiency of nutrients utilization became a concern. Humic acid 
(HA) is an end product of biodegradation processes of soil organic substances used as growth promoter (Galip et al., 2010). Previous studies reported that the addition of HA into the diet improved the animal health, stimulated nutrients digestion, growth and development of immune responses (Trckova et al., 2005). For instance, HA is known to have a beneficial impact on ruminal and intestinal microflora stabilization, ensuring enhanced feed efficiency. Nitrogenbinding capabilities of HA helped to minimize ammonia nitrogen $\left(\mathrm{NH}_{3}-\mathrm{N}\right)$ emissions from cattle feedlots (Ji et al., 2006). Moreover, addition of HA exhibited an inhibitory effect against toxins and infections and positively stimulated neutrophil activity as well as defence mechanisms against pathogens (Dabovich et al., 2003). The knowledge on the influence of HA administration in Barki goats on milk production and growth rate of their kids in Egypt is limited. Moreover, the present study sheds light on the impact of HA as a feed additive on ruminal fermentation characteristics, digestibility, productivity and health of goats and growth rate of their kids. It was hypothesised that HA as an organic additive could improve the productive performance of goats without negative effects on their health and health of their kids.

The objectives of this study were to examine the influence of HA on appraising rumen fermentation constituents, nutrients digestibility, blood biochemical parameters, response to parasites and milk yield of goats and growth of their kids.

\section{Material and methods}

All samples were analysed at the Advanced Laboratory of Animal Nutrition, Department of Animal Production, Faculty of Agriculture, Alexandria University and City of Scientific Research and Technological Application (SRTA-City, Egypt). The care of all goats was performed in accordance with the guidelines of treatment of agricultural animals in agricultural research and teaching.

\section{Experiment design and goats treatment}

Twenty late pregnant Barki goats $(45.40 \pm 1.5 \mathrm{~kg}$ body weight) were allotted into two treatments in a completely randomized design. Two weeks before the onset of the experiment, goats aging $35 \pm 0.3$ months, of similar lambing date and body weight, were selected from the farm flock. Goats were housed in individual pens with muddy floors bedded with rice straw. Each pen was equipped with feeder and water buckets. For 70 days goats were fed individually a basal diet as total mixed rations (TMR) with $40 \%$ forage and $60 \%$ concentrate $(\mathrm{F} / \mathrm{C})$ containing $200 \mathrm{~g}$ of maize silage, $200 \mathrm{~g}$ of Egyptian berseem clover (Trifolium alexandrinum L.), hay and $600 \mathrm{~g}$ of concentrate mixture per $\mathrm{kg}$ dry matter (DM) to meet their nutrient requirements according to National Research Council (NRC, 2007) recommendations (Table 1). Goats received basal TMR either without HA (control group, CTL) or were orally drenched with $2 \mathrm{~g} \cdot \mathrm{d}^{-1}$ of HA per goat (HA group) for 14 days prepartum (before the expected lambing date) and 56 days postpartum. Each HA dose was diluted in $50 \mathrm{ml}$ fresh water before each morning feeding and orally drenched to each goat in order to ensure that each goat receive the full dose of HA. Each $100 \mathrm{~g}$ of humate substances used in the present study (GTX Technologies, Amarillo, TX, USA) were composed of $90 \mathrm{~g}$ HA and $10 \mathrm{~g}$ minerals. Goats were fed similar equal portions of TMR twice a day at 08:00 and 16:00 allowing refusal amount of approximately $10 \%$ of daily dry matter intake (DMI). Water was available ad libitum. The experimental TMR ingredients and chemical composition are presented in Table 1.

Table 1. Ingredients and chemical composition of the experimental total mixed ration (TMR)

\begin{tabular}{lc}
\hline Indices & TMR diet \\
\hline Ingredients, $\mathrm{g} \cdot \mathrm{kg}^{-1} \mathrm{DM}$ & \\
maize silage & 200 \\
berseem hay & 200 \\
cracked maize & 378 \\
cottonseed meal & 60 \\
linseed meal & 60 \\
wheat bran & 90 \\
salt & 3 \\
limestone & 8.4 \\
mineral mixtures & \\
Chemical composition, $\mathrm{g} \cdot \mathrm{kg}^{-1} \mathrm{DM}$ & 0.6 \\
OM & \\
CP & 931.1 \\
EE & 143.5 \\
NFC & 39.1 \\
aNDFom & 363.1 \\
ADFom & 385.4 \\
hemicellulose & 172.8 \\
cellulose & 199.2 \\
lignin & 140.2 \\
AIA & 32.6 \\
\hline DIA & 11.55 \\
\hline
\end{tabular}

$\mathrm{DM}$ - dry matter; OM - organic matter; $\mathrm{CP}$ - crude protein; $\mathrm{EE}$ - ether extract; NFC - non-fibre carbohydrates; aNDFom - neutral detergent fibre assayed with a heat stable a-amylase and expressed inclusive of residual ash; ADFom - acid detergent fibre expressed exclusive of residual ash; AIA - acid insoluble ash; ${ }^{1}$ contained per kg: g: Mn 12.58 , Zn 9.3, Cu 3.2, Fe 16.67, Ca 0.081, Se 0.4, Mg 9.4, Co 0.2, NaCl added to $\mathrm{kg}$ (Dyno Vet Company, Alexandria, Egypt); ${ }^{2} \mathrm{NFC}$ calculated as: $1000-($ aNDFom $+\mathrm{CP}+\mathrm{EE}+\mathrm{ash})\left(\right.$ all in $\left.\mathrm{g} \cdot \mathrm{kg}^{-1} \mathrm{DM}\right)$ 


\section{Feed intake and sampling collection}

The DMI was measured as the difference between the total daily amount of feed offered per pen and the total daily amount of weighed-back orts after allowing approximately $10 \%$ of DMI refusal of daily amount. Samples of TMR were taken weekly from each pen throughout the experiment and frozen at $-20{ }^{\circ} \mathrm{C}$ for later chemical analyses.

\section{Rumen fermentation characteristics analyses}

On days 17, 34, 51 and 68 postpartum, $20 \mathrm{ml}$ of ruminal fluid were withdrawn $3 \mathrm{~h}$ post-feeding from each animal using a stomach tube (Ramos-Morales et al., 2014). After the collections, aliquot samples were strained through 4 layers of cheesecloth and then prepared for subsequent determination of $\mathrm{NH}_{3}-\mathrm{N}$ concentration, total number of protozoa count and short chain fatty acid (SCFA) analyses. Ruminal fluid $\mathrm{pH}$ was measured immediately after withdrawing using a portable $\mathrm{pH}$ meter (GLP 21 model; CRISON, Barcelona, Spain). Ruminal $\mathrm{NH}_{3}-\mathrm{N}$ concentration was measured colorimetrically with the use of spectrophotometer(Alpha-1101 model; Labnics Equipment, Fremont, CA, USA) using commercial lab test (SPINREACT, St. Esteve de Bas, Girona, Spain) as described by Konitzer and Voigt (1963). Aliquots of $2 \mathrm{ml}$ subsample were mixed with $4 \mathrm{ml}$ of methyl green-formalin-saline solution in glass bottle at room temperature for subsequent analyses of total protozoa counts (Onodera et al., 1977) using Neubauer improved bright-line counting chamber according to the procedure described by Dehority (1993). Individual SCFA concentrations were determined as described by Abo-Zeid et al. (2017) with some modifications using gas chromatography (GC) (TRACE1300, Thermo Fisher Scientific, Inc., Rodano, Milan, Italy) fitted with an AS3800 autosampler and equipped with a capillary column HP-FFAP (19091F-112; 0.320 mm o.d., $0.50 \mu \mathrm{m}$ i.d. and $25 \mathrm{~m}$ length; Agilent Technologies Inc., Palo Alto, CA, USA). Hydrogen at flow of $1.35 \mathrm{ml} \cdot \mathrm{min}^{-1}$ was used as carrier gas. Air, hydrogen and nitrogen fluxes (make up gas) were kept at 450, 40, and $35 \mathrm{ml} \cdot \mathrm{min}^{-1}$, respectively. A $0.1 \mu \mathrm{l}$ aliquot was injected in splitless mode for the entire run with $31.35 \mathrm{ml} \cdot \mathrm{min}^{-1}$ of $\mathrm{H}_{2}$ flux (63.432 Pa). Injector and flame ionization detector (FID) temperatures were held isothermally at $250^{\circ} \mathrm{C}$. Oven heating slope was $80{ }^{\circ} \mathrm{C}(1 \mathrm{~min}), 120^{\circ} \mathrm{C}\left(20^{\circ} \mathrm{C} \cdot \mathrm{min}^{-1}\right.$ for $\left.3 \mathrm{~min}\right)$, and $205^{\circ} \mathrm{C}\left(10^{\circ} \mathrm{C} \cdot \mathrm{min}^{-1}\right.$ for $\left.2 \mathrm{~min}\right)$, with 9 min overall analytical time.

\section{Apparent nutrients digestibility}

At the last 7 consecutive days of the experiment (days 64-70), fresh faecal grab samples (50 g each) were obtained daily from each animal at 09:00 and 17:00 about $1 \mathrm{~h}$ post-feeding. Apparent nutrients digestibility were calculated based on the relative concentrations of these nutrients and of acid insoluble ash (AIA) in the feed and faeces as an internal marker according to Van Soest et al. (1991). At the end of this period, all the aliquots of faeces from each animal were bulked and mixed completely, the pooled samples were dried in a forced air oven at $60{ }^{\circ} \mathrm{C}$ for $72 \mathrm{~h}$, ground to pass through a $1-\mathrm{mm}$ stainless steel screen using Wiley mill grinder and stored until chemical analyses.

\section{Blood sample analyses}

On days 17, 34, 51 and 68 postpartum, blood samples $(10 \mathrm{ml})$ were taken from jugular vein of each goat into heparinized tube before the morning feeding. The blood samples were centrifuged at $4000 \mathrm{~g}$ for $20 \mathrm{~min}$ and plasma was immediately frozen under $-20{ }^{\circ} \mathrm{C}$ for future processing. Blood total protein, albumin, urea, glucose and cholesterol levels were measured using commercial colorimetric kits (SPINREACT, St. Esteve de Bas, Girona, Spain) according to Tietz et al. (1995). Globulin concentration was calculated as the difference between the total protein and albumin values. The serum $\beta$-hydroxybutyrate (BHBA) concentration was determined by a kinetic enzymatic method using a commercially available kit (RANBUT D-3-hydroxybutyrate; Randox Laboratories Ltd., Crumlin, UK). Serum non-esterified free fatty acids (NEFA) concentration was measured using commercially available kit supplied by Randox Laboratories Ltd. (Crumlin, UK).

\section{Faecal sample collection for egg count analysis}

Individual faecal samples were collected at days $14,28,35,42,49,56,63$ and 70 throughout the experiment before the morning feeding to measure faecal egg count (FEC; without egg differentiation) using the modified McMaster technique (Ueno and Gonçalves, 1998).

\section{Milk sampling, yield and composition}

After the first 3 days of parturition, milk yield assessment was started to enable kids to learn to suckle their dam colostrum. Individual milk yield was measured at days 17, 34, 51 and 68 through- 
out the experiment (the same days used in blood and ruminal fluid sampling) using the oxytocin protocol (Zamiri et al., 2001). In brief, to elicit milk let-down, 5 min prior to milking goats received an intramuscular injection of commercially available oxytocin at a dose of 2 IU per animal per day (Oxitocina Diana; Super's Diana, S.L., Barcelona, Spain). Goats were re-milked approximately $4 \mathrm{~h}$ later in the same order as first milking and following the same protocol. The weight of milk in the second milking (between milking yield) was recorded to obtain an estimate milk production per day.

Individual fresh milk samples $(20 \mathrm{ml})$ were analysed for fat, lactose and protein contents by infrared methods (EKOMILK-M Ultrasonic Milk Analyzer, EON Trading Inc., Zagora, Bulgaria). Milk urea nitrogen (MUN) content was measured using commercial colorimetric kits (SPINREACT, St. Esteve de Bas, Girona, Spain) as described by Tietz et al. (1995). The somatic cell count (SCC) was determined by EKOMILKSCAN Somatic Cell Analyser (Bulteh 2000, Zagora, Bulgaria). Fat corrected milk $\left(F C M, \mathrm{~kg} \cdot \mathrm{d}^{-1}\right)$ was calculated as milk yield $\times$ $0.4+$ fat yield $\times 15$. Energy corrected milk $(\mathrm{ECM}$, $\left.\mathrm{kg} \cdot \mathrm{d}^{-1}\right)$ was calculated as $(0.3246 \times$ milk yield $)+$ $(12.86 \times$ fat yield $)+(7.04 \times$ protein yield $)$ according to Bernard (1997). Feed efficiency expressed as milk yield per unit of DMI was calculated.

\section{Kids performance and body weight gain}

Birth weight of kids was recorded directly after birth. All kids were weighted on days 30 and 60 postpartum to calculate average daily gain (ADG). Kids body weight at weaning was considered after 60 days of age and recorded after $8 \mathrm{~h}$ fasting period. Throughout the experiment, kids were allowed to stay with their does from 08:00 and 18:00 except for milk production estimation days.

\section{Laboratory analyses}

Feed, orts and faecal samples were thawed and dried in a forced-air oven at $60{ }^{\circ} \mathrm{C}$ for $72 \mathrm{~h}$ and ground to pass a 1-mm screen for future analyses. The dry matter (DM, ID number 930.15) was determined by oven drying at $105{ }^{\circ} \mathrm{C}$ for $24 \mathrm{~h}$, organic matter (OM, ID number 942.05) by the difference after heating at $550{ }^{\circ} \mathrm{C}$ for $4 \mathrm{~h}$, crude protein $(\mathrm{CP}$ as $6.25 \times \mathrm{N}$, ID number 954.01) by Kjeldahl technique and ether extract (EE, ID number 920.39) according to AOAC International (2006) methods. Sequential neutral detergent fibre (NDF) and acid detergent fibre (ADF) were determined as described by Van Soest et al. (1991). Analyses of NDF were performed using heat-stable $\alpha$-amylase and expressed exclusive of residual ash (aNDFom) using an ANKOM 200 Fibre Analyzer unit (ANKOM Technology Corp., Macedon, NY, USA). The ADF was expressed exclusive of residual ash (ADFom). Sequential in the same sample, lignin content of feed and faeces were determined according to Van Soest (1973) by solubilisation of ADF with $720 \mathrm{~g} \cdot \mathrm{kg}^{-1}$ sulphuric acid. Dietary content of non-fibre carbohydrates (NFC, $\mathrm{g} \cdot \mathrm{kg}^{-1}$ ) was calculated as $1000-($ aNDFom $\mathrm{g} \cdot \mathrm{kg}^{-1} \mathrm{DM}+\mathrm{CP} \mathrm{g} \cdot \mathrm{kg}^{-1} \mathrm{DM}+\mathrm{EE} \mathrm{g} \cdot \mathrm{kg}^{-1} \mathrm{DM}+$ ash $\mathrm{g} \cdot \mathrm{kg}^{-1} \mathrm{DM}$ ). The concentrations of cellulose (cellulose, $\mathrm{g} \cdot \mathrm{kg}^{-1} \mathrm{DM}=\mathrm{ADFom}-$ lignin) and hemicellulose (hemicellulose, $\mathrm{g} \cdot \mathrm{kg}^{-1} \mathrm{DM}=$ aNDFom ADFom) were calculated.

\section{Statistical analysis}

Data for DMI, rumen fermentation constituents ( $\mathrm{pH}, \mathrm{NH}_{3}-\mathrm{N}, \mathrm{SCFA}$ and protozoa number), blood biochemical parameters (total protein, albumin, globulin, urea, glucose, cholesterol, NEFA and BHBA concentrations), faecal egg count and lactation performance were analysed as a complete randomized design with two dietary treatments (CTL and HA) with repeated measures over time using the PROC MIXED procedure of SAS (version 9.1, 2002; SAS Institute Inc., Cary, NC, USA). The model was:

$$
Y i j=\mu+T i+D j+D T i j+E i j,
$$

where: $Y i j-$ dependent variable; $\mu$ - overall mean, $T i$ - effect of treatment $(i=1-2) ; D j-$ effect of sampling day $(j=1-4) ; D T i j$ - interaction of treatment $\times$ time; and Eij - residual error. Data for coefficient of digestion and kids performance were analysed using the GLM procedure of SAS following model as $Y i=\mu+T i+E i$, where: $\mu$ - overall mean; $T i$ - treatment effect $(i=1-2)$; and $E i$-residual error. Statistical differences among treatments were declared at $P \leq 0.05$, and tendencies were considered at $0.05<P \leq 0.10$.

\section{Results}

\section{Effects on ruminal fermentation constituents}

Ruminal $\mathrm{pH}$ increased $(P<0.001)$ when goats were drenched with HA in relation to CTL (6.58 vs 6.21 , respectively) and a significant effect $(P=0.007)$ of the experimental period was stated (Table 2). Ruminal $\mathrm{NH}_{3}-\mathrm{N}$ concentration was lower $(P=0.009)$ in goats administered with HA than in CTL ones (14.89 vs $12.43 \mathrm{mg} \cdot \mathrm{dl}^{-1}$, respectively). Administration of HA increased ruminal acetate $(\mathrm{C} 2,50.86$ vs $\left.56.66 \mathrm{~mol} \cdot 100 \mathrm{~mol}^{-1}, P=0.009\right)$ and propionate concentration $\left(\mathrm{C} 3,19.98\right.$ vs $22.02 \mathrm{~mol} \cdot 100 \mathrm{~mol}^{-1}$, 
Table 2. Influence of humic acid administration on ruminal fermentation constituents of goats ( $n=10$ per group)

\begin{tabular}{|c|c|c|c|c|c|c|}
\hline \multirow{2}{*}{ Indices } & \multicolumn{2}{|l|}{ Diet $^{1}$} & \multirow{2}{*}{ SEM } & \multicolumn{3}{|c|}{$P$-value ${ }^{2}$} \\
\hline & CTL & $\mathrm{HA}$ & & diet & day & diet $x$ day \\
\hline$\overline{\mathrm{pH}}$ & $6.21^{b}$ & $6.58^{\mathrm{a}}$ & 0.72 & $<.001$ & 0.007 & 0.629 \\
\hline $\mathrm{NH}_{3}-\mathrm{N}, \mathrm{mg} \cdot \mathrm{dl}^{-1}$ & $14.89^{a}$ & $12.43^{b}$ & 0.93 & 0.009 & 0.101 & 0.527 \\
\hline Total SCFA, mM & 92.10 & 98.78 & 2.10 & 0.123 & 0.803 & 0.783 \\
\hline \multicolumn{7}{|c|}{ SCFA, mol $\cdot 100 \mathrm{~mol}^{-1}$} \\
\hline acetate (C2) & $50.86^{b}$ & $56.66^{a}$ & 1.42 & 0.009 & 0.426 & 0.351 \\
\hline propionate (C3) & $19.98^{b}$ & $22.02^{\mathrm{a}}$ & 1.15 & 0.007 & 0.002 & 0.435 \\
\hline butyrate & 15.58 & 14.47 & 1.06 & 0.346 & 0.258 & 0.577 \\
\hline $\mathrm{C} 2: \mathrm{C} 3$ ratio & 2.79 & 2.72 & 0.15 & 0.751 & 0.003 & 0.223 \\
\hline $\begin{array}{l}\text { Protozoa, } \\
\times 10^{5} \mathrm{cell} \cdot \mathrm{ml}^{-1}\end{array}$ & $3.12^{\mathrm{a}}$ & $2.83^{b}$ & 0.08 & 0.053 & 0.142 & 0.302 \\
\hline
\end{tabular}

SCFA - short chain fatty acids; SEM - means standard error; ${ }^{1}$ diet: CTL - control as basal diet without humic acid, HA - basal diet plus humic acid; ${ }^{2}$ effects: diet - diet effect, day - day effect, diet $\times$ day - diet by day interaction effect; ${ }^{a b}$ - values within the same row with different subscripts are significantly different $(P<0.05)$

$P=0.007)$ in relation to CTL. Interestingly, there was a significant effect of sampling time on propionate concentration $(P=0.002)$ during the experiment progress. The $\mathrm{C} 2: \mathrm{C} 3$ ratio was not affected $(P=0.751)$ by HA administration but was affected $(P=0.003)$ by sampling time. Total number of protozoa was reduced $(P=0.053)$ by HA administration in relation to CTL $\left(3.12\right.$ vs $2.83 \times 10^{5} \mathrm{cell} \cdot \mathrm{ml}^{-1}$, respectively).

\section{Effects on DMI and apparent nutrients digestibility}

Actual DMI was reduced $(P<0.001)$ by administration of HA (1.040 vs $1.013 \mathrm{~kg} \cdot \mathrm{d}^{-1}$, Table 3$)$. However, in all goats, apparent nutrients digestibility was not affected $(P>0.05)$ with HA treatment.

Table 3. Influence of humic acid administration on dry matter intake (DMI) and nutrients digestibility of goats ( $n=10$ per group)

\begin{tabular}{|c|c|c|c|c|}
\hline \multirow{2}{*}{ Indices } & \multicolumn{2}{|l|}{$\operatorname{Diet}^{1}$} & \multirow{2}{*}{ SEM } & \multirow{2}{*}{$P$-value } \\
\hline & CTL & $\mathrm{HA}$ & & \\
\hline $\mathrm{DMI}, \mathrm{kg} \cdot \mathrm{d}^{-1}$ & $1.040^{\mathrm{a}}$ & $1.013^{b}$ & 7.08 & $<0.001$ \\
\hline \multicolumn{5}{|c|}{ Nutrients digestibility, $\mathrm{g} \cdot \mathrm{kg}^{-1}$} \\
\hline DM & 720.8 & 733.2 & 0.98 & 0.399 \\
\hline $\mathrm{OM}$ & 747.0 & 756.4 & 1.13 & 0.574 \\
\hline $\mathrm{CP}$ & 691.6 & 700.8 & 1.33 & 0.639 \\
\hline $\mathrm{EE}$ & 751.0 & 740.5 & 0.52 & 0.209 \\
\hline aNDFom & 613.5 & 612.8 & 1.29 & 0.968 \\
\hline ADFom & 547.7 & 563.0 & 1.82 & 0.568 \\
\hline hemicellulose & 670.5 & 655.9 & 2.23 & 0.659 \\
\hline
\end{tabular}

DM, OM, CP, EE, aNDFom, ADFom - see Table 1; SEM - means standard error; ${ }^{1}$ see Table 2 ; ${ }^{\text {ab }}$ - values within the same row with different subscripts are significantly different $(P<0.05)$

\section{Effects on blood metabolites and FEC}

Goats administrated with HA showed higher blood total protein $(P=0.015)$ and globulin $(P=0.003)$ concentrations than CTL ones (5.95 and 3.64 vs 5.51 and $3.06 \mathrm{~g} \cdot \mathrm{dl}^{-1}$, respectively, Table 4). Goats administrated with HA were characterised with decreased blood levels of BUN $(P=0.001)$, cholesterol $(P=0.010)$, NEFA $(P=0.001)$ and BHBA $(P<0.001)$ than CTL animals. Plasma glucose levels in goats administrated with HA were increased $(P=0.008)$ in comparison to CTL (49.77 vs $54.10 \mathrm{mg} \cdot \mathrm{dl}^{-1}$, respectively). A significant interaction of diet $\times$ day was found for glucose and cholesterol levels $(P<0.001$ and $P=0.001$, respectively). Administration of HA caused a significant decrease $(P=0.043)$ of total FEC relative to CTL (2.95 vs $2.57 \mathrm{egg} \cdot \mathrm{g}^{-1}$, respectively) and was affected by the day of sampling $(P<0.001$, Table 4$)$.

Table 4. Influence of humic acid administration on blood biochemical parameters and faecal egg count of goats ( $n=10$ per group)

\begin{tabular}{|c|c|c|c|c|c|c|}
\hline \multirow{2}{*}{ Indices } & \multicolumn{2}{|l|}{ Diet $^{1}$} & \multirow{2}{*}{ SEM } & \multicolumn{3}{|c|}{$P$-value ${ }^{2}$} \\
\hline & CTL & $\mathrm{HA}$ & & diet & day & diet $x$ day \\
\hline \multicolumn{7}{|l|}{ Blood profile } \\
\hline $\begin{array}{l}\text { total protein, } \\
\mathrm{g} \cdot \mathrm{dl}^{-1}\end{array}$ & $5.51^{\mathrm{b}}$ & $5.95^{\mathrm{a}}$ & 0.23 & 0.015 & 0.105 & 0.405 \\
\hline albumin, $\mathrm{g} \cdot \mathrm{dl}^{-1}$ & 2.45 & 2.31 & 0.13 & 0.172 & 0.415 & 0.627 \\
\hline globulin, $\mathrm{g} \cdot \mathrm{dl}^{-1}$ & $3.06^{b}$ & $3.64^{a}$ & 0.24 & 0.003 & 0.096 & 0.171 \\
\hline $\mathrm{BUN}, \mathrm{mg} \cdot \mathrm{dl}^{-1}$ & $14.89^{a}$ & $12.42^{b}$ & 0.67 & 0.001 & 0.101 & 0.527 \\
\hline $\begin{array}{l}\text { glucose, } \\
\mathrm{mg} \cdot \mathrm{dl}^{-1}\end{array}$ & $49.77^{b}$ & $54.10^{\mathrm{a}}$ & 2.10 & 0.008 & $<0.001$ & $<0.001$ \\
\hline $\begin{array}{l}\text { cholesterol, } \\
\mathrm{mg} \cdot \mathrm{dl}^{-1}\end{array}$ & $39.15^{\mathrm{a}}$ & $33.79^{b}$ & 2.67 & 0.010 & 0.006 & 0.001 \\
\hline $\mathrm{NEFA}, \mathrm{mmol} \cdot \mathrm{I}^{-1}$ & $0.469^{a}$ & $0.435^{b}$ & 0.02 & 0.001 & 0.193 & 0.175 \\
\hline $\mathrm{BHBA}, \mathrm{mmol} \cdot \mathrm{I}^{-1}$ & $10.716^{a}$ & $0.557^{b}$ & 0.02 & 0.001 & 0.442 & 0.637 \\
\hline $\mathrm{FEC}$, egg $\cdot \mathrm{g}^{-1}$ & $2.95^{\mathrm{a}}$ & $2.57^{\mathrm{b}}$ & 0.04 & 0.043 & 0.001 & 0.104 \\
\hline
\end{tabular}

BUN - blood urea nitrogen; NEFA - nonesterified fatty acids; BHBA - $\beta$-hydroxybutyrate; FEC - faecal egg count transformed by $\log 10(X+10)$; SEM - means standard error; ${ }^{1,2}$ see Table 2; $\mathrm{ab}-$ values within the same row with different subscripts are significantly different $(P<0.05)$

\section{Effects on milk yield and composition}

Milk, fat, protein, lactose, FCM and ECM yields increased $(P<0.05)$ with administration of HA in comparison to CTL (Table 5). High milk fat $(P<0.001)$ and protein $(P=0.002)$ contents were observed in HA treated animals. Goats drenched with HA showed also lower MUN level (11.85 vs $\left.10.28 \mathrm{mg} \cdot \mathrm{dl}^{-1}, P=0.032\right)$ and milk SCC (2.82 vs $2.57 \times 10^{3}$ cell $\cdot \mathrm{ml}^{-1}$ respectively, $\left.P=0.001\right)$. The milk SCC was also affected by the day of sampling $(P=0.013)$ in goats administrated with HA. Feed eficiency was increased $(P<0.001)$ by the administration of HA. 
Table 5. Influence of humic acid administration on milk yield and composition of goats ( $n=10$ per group)

\begin{tabular}{|c|c|c|c|c|c|c|}
\hline \multirow{2}{*}{ Indices } & \multicolumn{2}{|l|}{ Diet $^{1}$} & \multirow{2}{*}{ SEM } & \multicolumn{3}{|c|}{$P$-value ${ }^{2}$} \\
\hline & $\overline{\mathrm{CTL}}$ & $\mathrm{HA}$ & & diet & day & diet $x$ day \\
\hline $\begin{array}{l}\text { Milk production, } \\
\mathrm{kg} \cdot \mathrm{d}^{-1}\end{array}$ & $0.662^{b}$ & $0.784^{a}$ & 53.74 & 0.003 & 0.991 & 0.763 \\
\hline \multicolumn{7}{|l|}{ Yield, $g \cdot d^{-1}$} \\
\hline fat & $21.61^{b}$ & $27.76^{\mathrm{a}}$ & 1.74 & $<0.001$ & 0.610 & 0.234 \\
\hline lactose & $26.64^{b}$ & $33.86^{\mathrm{a}}$ & 1.79 & $<0.001$ & 0.986 & 0.608 \\
\hline protein & $17.98^{\mathrm{b}}$ & $23.79^{\mathrm{a}}$ & 3.05 & $<0.001$ & 0.863 & 0.136 \\
\hline FCM & $588.92^{\mathrm{b}}$ & $726.81^{\mathrm{a}}$ & 23.24 & $<0.001$ & 0.785 & 0.392 \\
\hline ECM & $627.48^{b}$ & $774.93^{\mathrm{a}}$ & 24.91 & $<0.001$ & 0.925 & 0.522 \\
\hline \multicolumn{7}{|c|}{ Milk composition, $\mathrm{g} \cdot \mathrm{kg}^{-1}$} \\
\hline fat & $32.63^{b}$ & $35.95^{\mathrm{a}}$ & 0.07 & 0.001 & 0.129 & 0.201 \\
\hline lactose & 40.45 & 42.39 & 0.24 & 0.364 & 0.349 & 0.975 \\
\hline protein & $27.37^{b}$ & $30.29^{a}$ & 0.16 & 0.002 & 0.762 & 0.231 \\
\hline MUN, $\mathrm{mg} \cdot \mathrm{dl}^{-1}$ & $11.85^{\mathrm{a}}$ & $10.28^{b}$ & 0.49 & 0.032 & 0.313 & 0.301 \\
\hline $\begin{array}{l}\text { SCC, } \\
\times 10^{3} \text { cell } \cdot \mathrm{ml}^{-1}\end{array}$ & $2.82^{\mathrm{a}}$ & $2.57^{b}$ & 0.13 & 0.001 & 0.013 & 0.420 \\
\hline \multicolumn{7}{|l|}{ Feed efficiency } \\
\hline $\begin{array}{l}\text { milk production/ } \\
\text { DMI }\end{array}$ & $0.637^{b}$ & $0.769^{a}$ & 0.05 & $5<0.001$ & 0.953 & 0.627 \\
\hline
\end{tabular}

FCM - fat corrected milk; ECM - energy-corrected milk; MUN - milk urea nitrogen; SCC - somatic cell count and transformed by log10 $(X+10)$; DMI - dry matter intake; SEM - means standard error; ${ }^{-1,2}$ see Table 2; ab - values within the same row with different subscripts are significantly different $(P<0.05)$

\section{Effects on kid performance and body weight gain}

Administration of HA showed similar $(P=0.977)$ kids birth weight (averaged $2.12 \mathrm{~kg}$ ) (Table 6). Live body weight gain of kids reared by goats administrated with HA was higher $(P<0.001)$ than of those reared by the goats in CTL group at 30 and 60 days of age after birth (4.34 vs 4.82 and $6.86 \mathrm{vs} 8.34 \mathrm{~kg}$, respectively). Consequently, kids born from goats administrated with HA showed 21 and $31 \%$ greater $(P<0.001)$ ADG than kids born from goats from CTL group (after 30 and 60 day, 63.64 vs 77.29 and 73.04 vs $95.84 \mathrm{~g} \cdot$ day $^{-1}$, respectively).

Table 6. Influence of humic acid administration on birth and weaning weight kids of goats ( $n=11$ per group)

\begin{tabular}{lcccc}
\hline Indices & Diet $^{1}$ & & \multirow{2}{*}{ SEM } & \multirow{2}{*}{$P$-value } \\
\cline { 2 - 3 } & $\mathrm{CTL}$ & $\mathrm{HA}$ & & \\
\hline Birth weight, $\mathrm{kg}$ & 2.11 & 2.12 & 0.05 & 0.977 \\
Body weight, $\mathrm{kg}$ & & & & \\
$\quad$ after 30 days & $4.34^{\mathrm{b}}$ & $4.82^{\mathrm{a}}$ & 0.07 & $<0.001$ \\
$\quad$ after 60 days (weaning) & $6.86^{\mathrm{b}}$ & $8.34^{\mathrm{a}}$ & 0.16 & $<0.001$ \\
Kids average daily gain, $\mathrm{g} \cdot \mathrm{d}^{-1}$ & & & & \\
$\quad$ after 30 days & $63.64^{\mathrm{b}}$ & $77.29^{\mathrm{a}}$ & 1.56 & $<0.001$ \\
$\quad$ after 60 days (weaning) & $73.04^{\mathrm{b}}$ & $95.84^{\mathrm{a}}$ & 2.45 & $<0.001$ \\
\hline
\end{tabular}

${ }^{1}$ see Table 2; SEM - means standard error; ab - values within the same row with different subscripts are significantly different $(P<0.05)$

\section{Discussion}

Effects on ruminal fermentation constituents. The use of HA, as an organic additive for lactating goats, is actually a novel approach. According to Van Soest (1994), the optimal ruminal $\mathrm{pH}$ ranges from 6.10 to 6.80 for rumen microbial proliferation. High ruminal $\mathrm{pH}$ value of goats treated with HA reflects a buffering capability of humate substances, which in turn possibly leads to stabilize ruminal acidity and manipulates ruminal changes toward improving efficiency of rumen microbial functions. Buffering abilities of HA could allow goats to reap the buffering benefits of HA which presented variable impacts of the treatments at different days of sampling. The results revealed lower ruminal $\mathrm{NH}_{3}-\mathrm{N}$ concentration in goats drenched with $\mathrm{HA}$. It may be connected with the effectiveness of humate substances to reduce $\mathrm{NH}_{3}-\mathrm{N}$ accumulation, which highlights the addition of HA as organic additive. Moreover, strong nitrogen-binding properties of HA may induced extra reduction of ruminal $\mathrm{NH}_{3}-\mathrm{N}$ (McMurphy et al., 2009). Dietary inclusion with HA may enhance CP utilization by decreasing $\mathrm{NH}_{3}-\mathrm{N}$ loss owing to reduced solubility under the inhibitory effects of HA on urease activity (Ji et al., 2006). This could reflect the higher ability of HA to cause a shift in nitrogen excretion from urine to faeces due to reduced solubility. The ability of HA to alter ruminal fermentability by sequestering $\mathrm{NH}_{3}$-Nand thenslowlyreleasingitformicrobial growth can be proven by about $20 \%$ reduction of ruminal $\mathrm{NH}_{3}-\mathrm{N}$ concentration. Thus reducing protozoa number may increase microbial crude protein (MCP) flow to the small intestine (Galip et al., 2010). Decreases in ruminal $\mathrm{NH}_{3}-\mathrm{N}$ concentration were accompanied by the reduction in protozoa counts. Ruminal C3 concentration were different between the sampling days, which could be a result of ruminal microbial population shift.

Effects on nutrients intake and apparent digestibility. Differences of DMI in response to HA administration were observed. Reduction in DMI could result from greater ruminal $\mathrm{C} 3$ concentration. Thus, lower DMI could be also attributed to increased plasma glucose in goats treated with HA, which may affect daily DMI (Allen et al., 2009). In general, the differences in ruminal fermentation patterns suggest that HA could have different mode of actions on microbial activities. Though the lack of effects of HA on whole digestibility of nutrients was not expected. Váradyová et al. (2009) reported similar nutrients digestibility in in vitro batch cultures supplemented 
with HA. Based on this discrepancy, it is reasonable to estimate that HA had a little impact on apparent nutrients digestibility, possibly related to the dose of HA, the adaptation period, sampling time or TMR composition used in this study.

Effects on blood metabolites and FEC. Higher total protein levels observed in goats receiving HA suggest that HA may modulate protein metabolism. Administration of HA increased globulin concentration, and such a rise could reflect the capability of humate substances to stimulate the immune system of animal (Trckova et al., 2005). In HA treated goats, lower BUN value is indicated by more efficient utilization of dietary $\mathrm{CP}$ for microbial protein synthesis associated with nitrogen-binding capabilities of HA. This low value of BUN confirmed the observation of Van Soest (1994) that lower BUN is usually associated with a lower ruminal $\mathrm{NH}_{3}-\mathrm{N}$ flux to bloodstream. Thus, reduction in BUN value could be supported by lower ruminal $\mathrm{NH}_{3}-\mathrm{N}$ concentration.

In the present study, the lower blood cholesterol level was found in goats drenched with HA. This finding confirms the ability of HA to reduce total cholesterol levels (HA decreases iron release from ferritin storage and as a consequence stimulates lipid peroxidation in dairy goats).

The high glucose level throughout the lactation period could enhance mammary glucose supply and thus stimulate milk lactose synthesis. In goats treated with HA also the increased amino acids uptake by the mammary gland might have been stated as a result of enhanced mammary blood flow. Higher glucose level can be a useful indicator for enhancement of goat energy status. In the present experiment, the levels of blood metabolites potentially indicate that goats administrated with HA were in normal physiological state (Kaneko et al., 2008) and have normal energy status, reflecting no adverse effects produced by HA administration. This might be the possible explanation for the lower feed DMI in goats supplied with HA. Additionally, greater ruminal $\mathrm{C} 3$ was associated with high liver gluconeogenesis raising plasma glucose concentration. This pattern was possibly related to rapid flux of ruminal $\mathrm{C} 3$ into bloodstream converted in the liver to glucose. Moreover, high level of NEFA and BHBA serves as an indicator of energy condition and lipolysis which coupled with high cholesterol levels (Ametaj et al., 2009). In goats fed HA diet there was found an increased blood glucose level in comparison to goats fed CTL diet, associated with lower NEFA and BHBA concentrations. This may indicate that HA increasing glucose level may improve the energy balance and simultaneously decreasing the risk for ketosis.

Reduced total FEC with HA treatment indicated a positive effect of the latter on stimulation of the immune system of animals to strengthen the resistance against pathogens (Trckova et al., 2005). Immune system stimulation due to HA antibiotic properties resulted in increased resistance to diseases, as well as parasite manifestation due to the antiparasitic activity of humate substances.

Effects on milk yield, composition and kids performance. In the present experiment, administration of HA enhanced daily milk yield by about $18 \%$. Better milk yield and composition observed in animals fed HA may result from better nutrients utilisation induced by HA addition. It is supposed that the use of humic substances can stimulate cell membrane metabolic activities due to the accelerated oxidative processes leading to more efficient nutrients uptake. Enhanced lactation performance in goats treated with HA may be connected also with better rumen parameters. Moreover, increased yield of milk constituents (fat, lactose, protein) resulted from higher milk production observed in HA group.

In goats treated with HA increased milk fat content might be the consequence of high ruminal $\mathrm{C} 2$ concentration (precursor of milk fatty acids), which could probably enhance de novo fatty acid synthesis in mammary gland. However, higher fat content in milk may also be a result of increased exogenous fatty acids uptake from the gastrointestinal tract. Higher blood glucose level could have an impact on higher milk protein yield in HA goats. In comparison to CTL about $24 \%$ higher ECM was connected with higher milk fat yields found in goats fed HA. However, changes in feed efficiency could be mostly due to differences in milk production. The observed decreased level of MUN in goats fed diet with HA can be explained by lower BUN level which resulted from lower ruminal $\mathrm{NH}_{3}-\mathrm{N}$ concentration. In the present study, MUN result fits very well with the reduction of $\mathrm{BUN}$ and ruminal $\mathrm{NH}_{3}-\mathrm{N}$ obtained.

Mastitis, an inflammation of the mammary gland caused by bacterial infection, damages glandular tissue causing lower milk yield and elevates SCC (Sharma et al., 2011). Regardless of mastitis, lower milk yield in ewes is known to be positively associated with higher SCC. The results of present study showed 9\% reduction in milk SCC in animals fed HA. Moreover, there was observed the influence of the sampling day (the longer administration the lower SCC value in milk). This could be connected with nutriceutical properties of HA which mode of 
action stimulates neutrophil activity to protect the animal organs against pathogenic bacteria (Dabovich et al., 2003). This is in contrast to the results of Degirmencioglu and Ozbilgin (2013) on Saanen goats.

Kids weaned from goats administrated with HA were heavier than those from CTL group and had $31 \%$ greater ADG after 60 days. This could be justified by higher milk yield, quality and efficiency. It is also important that HA was administered during late pregnancy and whole lactation period, which allowed to produce high quality colostrum and then milk. Increasing the availability of nutrients supply to lactating goats might directly improve performance and growth rate of their kids. Therefore, it could be suggested that the better pre-weaning ADG of kids will positively affect post-weaning efficiency. Wang et al. (2008) found that HA additive improved animal gut health, nutrients absorption and nutritional status. Differences in suckling kids growth performance are basically related to changes in milk yield, as well as milk fat and protein contents (Manso et al., 2011). The novel appearance of goats administrated with HA may positively confirm the enhancement of immune system responses accompanied with low value of SCC. These findings explain that HA is a novel feed additive that can raise kids growth rate up to $31 \%$.

\section{Conclusions}

Humic acid (HA) could be used to modulate the ruminal fermentation pattern by shifting ruminal fermentability to more efficient end products. Also, administration of HA improved goats milk yield and quality, and growth rate of their kids with no adverse effects on goat health. Responses to HA as a natural additive, however, may be dose-dependent. Nevertheless, further research evaluating HA long-term mode of action and its influence on nitrogen metabolism (dose vs the most favourable responses) is needed.

\section{References}

Abo-Zeid H.M., El-Zaiat H.M., Morsy A.S., Attia M.F.A., Abaza M.A., Sallam S.M.A., 2017. Effects of replacing dietary maize grains with increasing levels of sugar beet pulp on rumen fermentation constituents and performance of growing buffalo calves. Anim. Feed Sci. Technol. 234, 128-138, https://doi. org/10.1016/j.anifeedsci.2017.09.011

Allen M.S., Bradford B.J., Oba M., 2009. The hepatic oxidation theory of the control of feed intake and its application to ruminants. J. Anim. Sci. 87, 3317-3334, https://doi.org/10.2527/ jas.2009-1779
Ametaj B.N., Emmanuel D.G.V., Zebeli Q., Dunn S.M., 2009. Feeding high proportions of barley grain in a total mixed ration perturbs diurnal patterns of plasma metabolites in lactating dairy cows. J. Dairy Sci. 92, 1084-1091, https://doi.org/10.3168/jds.20081465

AOAC International, 2006. Official Methods of Analysis of AOAC International. Current through revision 1. 18 ${ }^{\text {th }}$ Edition. Gaithersburg, MD (USA)

Bernard J.K., 1997. Milk production and composition responses to the source of protein supplements in diets containing wheat middlings. J. Dairy Sci. 80, 938-942, https://doi.org/10.3168/jds. S0022-0302(97)76017-X

Dabovich L.A., Hulbert L., Rudine A., Kim S., Ji F., McGlone J., 2003. Evaluation of nutriceutical effects on pig immunity: effects of Promox. In: Proceedings of Annual Meeting of Southern Section of American Society of Animal Science. Mobile, AL (USA), abstract no. 114

Degirmencioglu T., Ozbilgin S., 2013. Effect of administration of humic acid on somatic cell count and total bacteria in Saanen goats. Int. J. Vet. Sci. 2, 151-154

Dehority B.A., 1993. Laboratory Manual for Classification and Morphology of Rumen Ciliate Protozoa. CRC Press Inc. Boca Raton, FL (USA)

Galip N., Polat U., Biricik H., 2010. Effects of supplemental humic acid on ruminal fermentation and blood variables in rams. Ital. J. Anim. Sci. 9, e74, https://doi.org/10.4081/ijas.2010.e74

Ji F., McGlone J.J., Kim S.W., 2006. Effects of dietary humic substances on pig growth performance, carcass characteristics, and ammonia emission. J. Anim. Sci. 84, 2482-2490, https://doi. org/10.2527/jas.2005-206

Kaneko J.J., Harvey J.W., Bruss M.L., 2008. Clinical Biochemistry of Domestic Animals. Academic Press (Elsevier). Burlington, MA (USA)

Konitzer K., Voigt S., 1963. Direct determination of ammonium in blood and tissue extracts by means of the phenol by chlorite reaction (in German). Clin. Chim. Acta 8, 5-11

Manso T., Bodas R., Vieira C., Mantecón A.R., Castro T., 2011. Feeding vegetable oils to lactating ewes modifies the fatty acid profile of suckling lambs. Animal 5, 1659-1667, https:// doi.org/10.1017/S1751731111000632

McMurphy C.P., Duff G.C., Harris M.A., Sanders S.R., Chirase N.K., Bailey C.R., Ibrahim R.M., 2009. Effect of humic/fulvic acid in beef cattle finishing diets on animal performance, ruminal ammonia and plasma urea nitrogen concentration. J. Appl. Anim. Res. 35, 97-100, https://doi.org/10.1080/09712119.2 009.9706995

NRC (National Research Council), 2007. Nutrient Requirements of Small Ruminants: Sheep, Goats, Cervids, and New World Camelids. The National Academies Press. Washington, DC (USA), https://doi.org/10.17226/11654

Onodera R., Yamaguchi H., Eguchi C., Kandatsu M., 1977. Limits of survival of the mingled rumen bacteria in the washed cell suspension of rumen ciliate protozoa. Agric. Biol. Chem. 41, 2465-2466, https://doi.org/10.1080/00021369.1977.108628 82

Ramos-Morales E., Arco-Pérez A., Martín-García A.l., YáñezRuiz D.R., Frutos P., Hervás G., 2014. Use of stomach tubing as an alternative to rumen cannulation to study ruminal fermentation and microbiota in sheep and goats. Anim. Feed Sci. Technol. 198, 57-66, https://doi.org/10.1016/j.anifeedsci.2014.09.016 
Sharma N., Singh N.K., Bhadwal M.S., 2011. Relationship of somatic cell count and mastitis: an overview. Asian-Australas. J. Anim. Sci. 24, 429-438, https://doi.org/10.5713/ajas.2011.10233

Tietz P.S., Holman R.T., Miller L.J., LaRusso N.F., 1995. Isolation and characterization of rat cholangiocyte vesicles enriched in apical or basolateral plasma membrane domains. Biochemistry 34, 15436-15443, https://doi.org/10.1021/bi00047a007

Trckova M., Matlova L., Hudcova H., Faldyna M., Zraly Z., Dvorska L., Beran V., Pavlik I., 2005. Peat as a feed supplement for animals: a literature review. Vet. Med.50, 361-377, https://doi. org/10.17221/5635-VETMED

Ueno H., Gonçalves P., 1998. Manual for the diagnosis of ruminant helminthes. $4^{\text {th }}$ Edition (in Portuguese). Japan International Cooperation Agency. Tokyo (Japan)

Van Soest P.J., 1973. Collaborative study of acid-detergent fiber and lignin. J. AOAC 56, 781-784

Van Soest P.J., 1994. Nutritional Ecology of the Ruminant. $2^{\text {nd }}$ Edition. Cornell University Press. Ithaca, NY (USA)
Van Soest P.J., Robertson J.B., Lewis B.A., 1991. Methods for dietary fiber, neutral detergent fiber, and nonstarch polysaccharides in relation to animal nutrition. J. Dairy Sci. 74, 3583-3597, https://doi.org/10.3168/jds.S0022-0302(91)78551-2

Váradyová Z., Kišidayová S., Jalč D., 2009. Effect of humic acid on fermentation and ciliate protozoan population in rumen fluid of sheep in vitro. J. Sci. Food Agric. 89, 1936-1941, https://doi. org/10.1002/jsfa.3675

Wang Q., Chen Y.J., Yoo J.S., Kim H.J., Cho J.H., Kim I.H., 2008. Effects of supplemental humic substances on growth performance, blood characteristics and meat quality in finishing pigs. Livest. Sci. 117, 270-274, https://doi.org/10.1016/j. livsci.2007.12.024

Zamiri M.J., Qotbi A., Izadifard J., 2001. Effect of daily oxytocin injection on milk yield and lactation length in sheep. Small Ruminant Res.40, 179-185, https://doi.org/10.1016/S09214488(01)00166-3 